\title{
Gender Diversity in the Boardroom and Corporate Philanthropy:
}

\section{Evidence from Nigeria}

\author{
Musa Inuwa Fodio ${ }^{1}$ Victor Chiedu Oba ${ }^{2 *}$ \\ 1. Department of Accounting, University of Abuja, PMB 114 University of Abuja, Nigeria \\ 2. Doctoral Candidate, Department of Accounting, Nasarawa State University, Keffi ,Nigeria \\ * E-mail of the corresponding author: oba156@yahoo.com
}

\begin{abstract}
This study basically investigates the association between boards' gender mix and corporate philanthropy among listed firms in Nigeria. To achieve the objective of this study, a total of twenty five listed firms were selected through a stratified random sampling technique. A multiple regression analysis was used to test the research propositions in this study. The study observed that there is a significant association between the gender diversity in the board room and the level of corporate philanthropy among listed firms in Nigeria. The paper therefore calls for a consideration of boards' gender diversity by management and government in order to explore the possible advantages associated with corporate giving.
\end{abstract}

Keywords: Social responsibility, labor discrimination, corporate governance, heterogeneity

\section{Introduction}

Corporate social Responsibility (CSR) is a burning issue in Nigeria. Organizations are being called upon to take responsibility for the ways their operations impact societies and the natural environment. Firms can no longer ignore the environment in which they operate, thus entrenching CSR as a corporate dictate. There is therefore a social implied contract between organizations and society.

In Nigeria, CSR has more of a philanthropic face as this is given the highest priority (Adeyanju, 2012). This is because the socio-economic demands of the Nigerian societies in which these organizations operate are at the highest, thus philanthropy and charity has become an expected value. Nigerian societies almost completely survive on aids (both foreign and local) and the consequent effect is a reliance on philanthropy. Nevertheless, philanthropic giving on one hand can be engaged in as a "strategic" behavior that is designed to enhance corporate reputation and image and then eventually have a ripple effect on the bottom line. Prior researchers have tied financial performance of organizations to their philanthropic and social responsibility initiatives (Waddock and Graves, 1997; Tsoutsoura, 2004; Orlitzky et al, 2003).

On the other hand, while corporate philanthropy may not yield direct tangible results to companies, scholars argue that it nonetheless needs to be viewed as a strategic investment which can yield significant returns.

Furthermore, philanthropic activity could in a sense serve as a form of 'reputational capital' (Formbrun, 1996) or as a means of co-opting stakeholders (Pfeffer and Salancik, 1978). As a result, the idea of Philantropy has become increasingly important to organizations, society and government (Buchlotz, Amason and Rutherford, 1999; Post and Waddock, 1995; Saiia et al, 2003).

Successes and failures of organizations are hinged on the decisions of senior management and board of directors. The board of directors are charged with the decision making mandate. According to Bernardi and Threadgill (2010), personality may have a tangible effect on the decision making process. Such personality concern in the decision making process can be due to the board's gender composition as found in literature (Williams, 2003). Williams (2003) finds that boards with higher number of women engage in charity giving to a larger extent than boards with less number of women.

Given the situation of labor discrimination and gender inequality prevalent in developing economies like Nigeria, women found in boards are so few and thus regarded as 'token' (Scherer, 1997). Consequently, this study examines 
whether an increased female representation on boards translates to outcomes in corporate philanthropy in Nigeria.

\section{2 .Prior Research, Hypotheses Development and Theoretical Underpinnings}

Companies With high female representation on their boards tend to have stronger corporate governance than those with few or no women on the board of directors (Rosener, 2003) and consider the needs of a wider range of stakeholders than male directors (Konrad and Kramer, 2006).

According to Stephenson (2004), more women on the board results in a major increase in the use of non-financial performance measures, such as innovation and social community responsibility. Bear et al (2010) find that the number of women board members is positively associated with CSR strength ratings, and that women are more inclined to make decisions with a networking focus (Hersby et al, 2009).

Scholars argue that boards with three or more women are determinants for CSR disclosure (Fernandez-Feijoo et al, 2012). They further demonstrate that such boards produce less integrated reports, inform more on CSR strategy and include assurance statements. Fernandez-Feijoo et al, (2012) conclude that the inclusion of women in boards mediates and moderates the effect of cultural characteristics on CSR reporting. On the other hand, Konrad et al (2008) discuss that when boards have at least three (3) women, they feel more comfortable being themselves, feel freer to raise issues and are more active. In any case, as members of underrepresented groups in organizations, female directors are expected to be more interested in the welfare of various stakeholders. Given the aforementioned findings, we expect that boards with a reasonable proportion of female directors will be more philanthropic in decision making. Along this line, we hypothesize that:

$\mathrm{H}_{1}-$ The proportion of female directors will impact on the level of corporate philanthropy.

$\mathrm{H}_{2}$ - Board heterogeneity will significantly impact on the level of philanthropy.

The study controls for the possible influence of firm size because larger firms tend to be more concerned with their corporate reputation and image; since they are more visible to external shareholders who constantly demand for a higher environmental performance and reporting (Uwalomwa, 2011). Along the line of Kyereboah - Coleman and Biekpe (2006), firm size is measured as the logarithmic transformation of the firm's total assets to base 10. This transformation is done because of its widely spread values. Thus we hypothesize that:

H3 - Firm size has a significant influence on corporate philanthropy.

This study is anchored on the legitimacy and resource dependency theories. 'Legitimacy' is said to exist as there is congruence between the activities of the organization and societal expectations. The legitimacy theory justifies the concept and practice of philanthropy and social responsibility initiatives by companies. The theory suggests that companies can operate effectively when the practice by a company is congruent with the value of the society. On the other hand, the resources dependency theory considers agents as a resource since they influence the environment in favor of the firm. It further suggests that the selection of a diverse board will provide more resources, information and legitimacy to the board (Johnson et al, 1996).

\section{Methodology}

This study uses a survey research design. The population of the study is made up of companies listed on the floor of the Nigerian stock exchange; however, firms belonging to the financial and utility services are excluded because of the special regulatory environment in which they operate. A sample of twenty five (25) quoted firms for the period 2005-2007 was selected using the stratified random sampling approach.

The sample selection conforms to the arguments of Emory and Cooper (2003) that the ultimate test of a sample design is how well it represents the characteristics of the population it purports to represent. The sample size is also in conformity to Krejcie and Morgan (1970) minimum sample size determination and also the modern online sample size calculator by Raosoft, Inc.

\subsection{Dependent variable}

Corporate philanthropy is represented by the total charitable donations made to bodies, associations or groups. Such donations must have been made to bodies permitted by the Companies and Allied Matters Act (1990). 


\subsection{Independent variables}

1. Proportion of female directors on the board to board size.

2. Gender diversity - The degree of heterogeneity of the board's gender was calculated using Blau's index; a commonly used diversity index named after Blau, P.M (1997) for measuring evenness. It is specified as follows:

$$
\begin{gathered}
\mathrm{n} \\
\mathrm{E} \mathrm{Pi} \mathrm{i}^{2} \\
\mathrm{i}=1
\end{gathered}
$$

Where $\mathrm{p}$ is the percentage of individuals in the ith category and $\mathrm{n}$ is the number of categories. Since Gender is a dichotomous variable, the range of the index is between 0 and 0.5 . As such, the closer to 0.5 , the more diverse and the closer to 0 , the less diverse.

\subsection{Control variable}

The control variable 'size' is measured as the logarithmic transformation of total assets to base 10 .

\subsection{Model specification}

The model is expressed thus:

$\mathrm{CP}=\mathrm{B}_{\mathrm{O}}+\mathrm{B} 1 \mathrm{PFD}+\mathrm{B}_{2} \mathrm{BD}+\mathrm{U}_{\mathrm{it}}$

Where $\mathrm{CP}=$ Corporate philanthropy

$\mathrm{PFD}=$ Proportion of female directors to board size

$\mathrm{BD}=$ Gender Diversity (Blau's index)

$\mathrm{U}_{\mathrm{it}}=$ Stochastic disturbance term.

Using the combinatorial method to control for the influence of firm size in the equation, the model turns out thus:

$\mathrm{CP}=\mathrm{B}_{\mathrm{O}}+\mathrm{B}_{1} \mathrm{PFD}+\mathrm{B}_{2} \mathrm{BD}+\mathrm{B}_{3} \mathrm{FS}+\mathrm{U}_{\mathrm{it}}$

All variable definitions remain the same while FS $=$ Firm size as denoted by $\log _{10}$ total assets.

\section{Results and Discussions}

The classical linear regression model assumes that each $U_{i}$ is distributed normally. Such normality assumption is emphasized in small samples. A violation of this assumption could render estimates indeterminate. A test of normality using the normal probability plot showed that the residuals in this study were not normally distributed. An approach to treating non-normality is to transform the variables into a natural logarithm (Gujarati and Porter, 2009). As such, all variables in the study were transformed likewise to a log base 10 . The results are as shown below:

\begin{tabular}{|c|c|c|c|c|}
\hline & PFD & $\mathrm{BD}$ & $\mathrm{CP}$ & FS \\
\hline $\begin{array}{ll} & \text { Pearson } \\
\text { PFD } & \text { correlation }\end{array}$ & 1 & $.787^{* *}$ & .204 & $-341^{*}$ \\
\hline Sig 2 tailed & & .000 & .318 & .049 \\
\hline $\mathrm{N}$ & 34 & 34 & 26 & 34 \\
\hline $\begin{array}{ll} & \text { Pearson } \\
\text { BD } & \text { correlation }\end{array}$ & $.787 * *$ & 1 & 116 & -.334 \\
\hline Sig 2 tailed & .000 & & .573 & .054 \\
\hline
\end{tabular}

Table 1: Correlations 
Research Journal of Finance and Accounting

ISSN 2222-1697 (Paper) ISSN 2222-2847 (Online)

Vol 3, No 8, 2012

\begin{tabular}{|c|c|c|c|c|c|}
\hline & $\mathrm{N}$ & 34 & 34 & 26 & 34 \\
\hline \multirow[t]{3}{*}{$\mathrm{CP}$} & $\begin{array}{l}\text { Pearson } \\
\text { correlation }\end{array}$ & .204 & .116 & 1 & .237 \\
\hline & Sig 2 tailed & .318 & .573 & & .091 \\
\hline & $\mathrm{N}$ & 26 & 26 & 52 & 52 \\
\hline \multirow[t]{3}{*}{ FS } & $\begin{array}{l}\text { Pearson } \\
\text { correlation }\end{array}$ & $-.341 *$ & -.334 & .237 & 1 \\
\hline & Sig 2 tailed & .049 & .054 & .091 & \\
\hline & $\mathrm{N}$ & 34 & 34 & 52 & 75 \\
\hline
\end{tabular}

**Correlation is significant at the 0.01 level ( 2 tailed)

*Correlation is significant at the 0.05 level ( 2 tailed)

Table 2: Coefficients

\begin{tabular}{|l|l|l|l|l|l|}
\hline & \multicolumn{2}{|l|}{ Unstandardized coefficients } & $\begin{array}{l}\text { Standardized } \\
\text { coefficients }\end{array}$ & & \\
\hline & B & Std.error & Beta & t & Sig \\
\hline (constant) & 8.623 & 1.842 & & 4.681 & .000 \\
\hline PFD & 15.909 & 5.376 & 3.164 & 2.959 & .007 \\
\hline BD & 18.421 & 6.459 & 3.033 & 2.852 & .009 \\
\hline FS & -.095 & .289 & -.066 & -.329 & .745 \\
\hline
\end{tabular}

a. Dependent variable: $\mathrm{CP}$

Table 3: Model Summary

\begin{tabular}{|l|l|l|l|l|l|}
\hline Model & R & R square & Adjusted R Square & Std. error of the estimate & Durbin-Watson \\
\hline 1 & $.551^{\mathrm{a}}$ & .304 & .209 & .75969 & 1.980 \\
\hline
\end{tabular}

a. Predictors: (constant), PFD, BD, FS

b. Dependent variable: $\mathrm{CP}$

Table 4: Anova ${ }^{b}$

\begin{tabular}{|l|l|l|l|l|l|}
\hline Model & $\begin{array}{l}\text { Sum of } \\
\text { squares }\end{array}$ & df & Mean square & F & Sig \\
\hline & 5.545 & 3 & 1.848 & 3.202 & $.043^{\mathrm{a}}$ \\
\hline Residual & 12.697 & 22 & .577 & & \\
\hline Total & 18.241 & 25 & & & \\
\hline
\end{tabular}

a. Predictors: (constant), PFD, BD, FS

b. Dependent variable: $\mathrm{CP}$

Table1 gives the correlations among the dependent variable CP and Independent variables PFD, BD and FS. This correlation matrix shows the association between these variables. From this table, it is clear that a positive correlation exists between proportion of female directors and the Blau's index of heterogeneity. This is just as expected; because the higher the proportion of female directors in the board room, the more diverse gender-wise the board is. A 
significant negative association was observed between the proportion of female directors and the firm size. In other words, the bigger the firm, the fewer the number of women directors and vice versa. One possible explanation for this could be that smaller firms seem to incorporate more female directors so as to enhance their corporate image and reputation while big firms might not consider such gender mix as a factor going by their already existing visibility and established image.

Hair et al (1987) document that a correlation matrix is free from multicollinearity when correlation coefficients fall below 0.8 or 0.9 . In this study, multicollinearity does not appear as a problem in interpreting the result since the highest Pearson correlation coefficient is below the threshold of 0.8 .

Table 2 tells us about the relationship that exists between proportion of women directors, Blau diversity index, Firm size and corporate philanthropy. Both proportion (PFD) and diversity index (BD) have been found to be positively statistically significant in predicting philanthropy. This seems to agree with the findings of Williams (2003) that having women on boards of directors was positively related to firm's corporate philanthropy. It also lends support to the work of Siciliano (1996) who demonstrated that organizations with more equal representation of female and male board members are more able to fulfill social agency missions.

Firm size was documented to have a neutral effect on corporate philanthropy. The findings seems to conflict with the investigations of Galaskiewiez (1997), Boatsman and Gupta (1997) and Amato and Amato (2007). They all argue that a key factor that influences corporate philanthropy is firm size. However, our findings lend credence to the work of Seifert et al (2004) whose investigation did not reveal any statistical significant relationship of firm size with corporate giving. The adjusted R square stood at .209. In other words, $21 \%$ of the variation in corporate philanthropy is explained by the proportion of women in the board. This is a reasonable goodness of fit since there certainly exists other factors that could explain for changes in the level of philanthropy aside gender. The Durbin Watson statistic of the study at 1.980 suggests the absence of autocorrelation in the model; while our F-Statistic with $\mathrm{P}$ value $(.043)<$ 0.05 guarantees the overall significance of the model.

\section{Conclusion and Recommendations}

The goal of this paper was to investigate the impact of female directors in the board room on corporate philanthropy. We identified that there exists a positive statistical impact of proportion of female directors and the degree of gender diversity on philanthropy. This is no surprise; it goes to confirm the study's initial hypothesis. As such, companies wishing to increase their socially responsible behavior via philanthropy may want to consider having more female board members. A negative association between firm size and corporate giving was identified. We argue that a possible explanation for this was that smaller firms needed to enhance their corporate image and reputation by introducing female board members as 'tokens' (Kanter, 1977), while large boards had no need to trade or gamble on performance with a gender balance since they are already societally and economically visible. However, the effects of philanthropy as an element of social responsibility on employees, public image and communities are far reaching (Bernardi and Threadgill, 2010), and many companies look for any available advantage in these areas. An increase of women on their boards can open these organizations to a world of opportunities. In line with Bilimoria (2000), more efforts need to be made to disseminate research investigations so that a stronger business case can be established. Governments might also have to monitor the effectiveness of diversity policies and practices and thus using robust research results to design possible interventions. Such robust research results according to Terjesen et al (2009) are an important tool not only for academic contribution, but also to provide a basis for a more effective gender representation at the decision-making echelons of the corporate world.

\section{References}

Adeyanju, D.O. (2012). An assessment of the impact of corporate social responsibility on Nigerian society: The examples of banking and communication industries, Universal Journal of Marketing and Business Research Vol. (1) pg $17-43$.

Amato, L.H. and Amato, C.H. (2007). The effects of firm size and industry on corporate giving, Journal of Business Ethics 72 (3), 229-241.

Buchhohz, A.K., Amason, A.C. and Rutherford, M.A. (1996). Beyond resources: The mediating effects of top management discretion and values on corporate philanthropy, Business and Society 38 (2): 167-187.

Bear, S., Ratman, N. and Post, C. (2010). The impact of board diversity and gender composition on corporate social responsibility and firm reputation, Journal of Business Ethics. No. 97, pp. 207-231. 
Bernardi, R.A. and Threadgill, V.H. (2010). Women directors and corporate social responsibility, Electronic Journal of Business Ethics and Organization Studies. Vol. 15, No. 2 pp. 15 - 21.

Bilimoria, D. (2000). Building the business case for women corporate directors. In Burke, R. and Mattis, M. (eds.) women on corporate boards of Directors: International Challenges and Opportunities, 25 - 40.

Blau, P.M. (1977). Inequality and Heterogeneity, The Free Press. New York.

Boatsman, J.R. and Gupta, S. (1996), Taxes and corporate Charity: Empirical Evidence from micro-level data. National Tax Journal, 49(2): 193 - 213.

Emory, C.W. and Cooper, D.R. (2003). Business Research Methods $\left(4^{\text {th }}\right.$ ed) Illinois: Richard D. Irwin Inc. Fernandez - Feijoo, B; Romero, S. and Ruiz, S. (2012). Does board gender composition affect corporate social responsibility reporting?, International Journal of Business and Social Science. Vol. 3, No. 1 Pp 31 - 38.

Formbrun, C.J. (1996). Reputation: Realizing value from the Corporate Image. Harvard Business School Press, Boston, Mass.

Galaskiewiez, J. (1997). An Urban Grants Economy Revisited: Corporate charitable contributions in the Twin Cities, 1979 - 1981, 1987 - 1989, Administrative Science Quarterly 42 (3), Pp 445 - 447.

Gujarati D.N. and Porter, D.C. (2009). Basic Econometrics. McGraw-Hill Fifth Edition, New York.

Hair, J.R., Anderson, R. and Tatham, D. (1987). Multivariate Data Analysis. MacMillan publishing company, New York.

Hersby, M.D. Ryan, M.K. and Jatten, J. (2009). Getting together to get ahead: The impact of social structure on women's networking, British Journal of Management 20 pp. 415 - 430.

Johnson J.L., Daily, C.M. and Ellstrand, A.E. (1996). Boards of directors: A review and research agenda, Journal of Management, 22 (3): $409-438$.

Kanter, R.M. (1977). Some effects of proportions on group life: Skewed sex ratios and responses to token women, American Journal of Sociology Vol. 82. No. 5 pp 965 - 990.

Konrad, A. and Kramer, V.W. (2006). How many women do boards need?, Harvard Business Review. Vol. 84 No. 12 p. 22.

Konrad, A.M., Kramer, V. and Erkut, S. (2008). Critical mass: The impact of three or more women on corporate boards, Organizational Dynamics 37 (2): pp 145 - 164.

Krejcie, R.V. and Morgan, D.W. (1970). Determining Sample size for research activities, Educational and psychological measurement. Vol. 20 pp. $607-610$.

Kyereboah - Coleman, A. and Biekpe, N. (2006). The Relationship between Board size, Board composition, CEO duality and Firm Performance: Experience from Ghana. Working paper. University of Stellenbosch Business School cape Town, South Africa.

Orlitzky, M; Schmidt, F. and Rynes, D.L. (2003). Corporate Social and Financial Performance: A Meta-Analysis, Organization Studies. Vol. 24 No. 3 pp $403-441$.

Pfeffer, J. and Salancik, G. (1978). The external control of organizations. A resource-dependence perspective. Harper and Row, New York.

Post, J.E. and Waddock, S.A. (1995). Strategic philanthropy and Partnerships for Economic Progress, Philanthropy and Economic Development. In America, R.F. (ed), Philanthropy and Economic Development 167 - 191. Westport, CT: Greenwood.

Rosener, J.B. (2003). Women on corporate boards make good business sense, Directorship Vol. 29, No. 5 pp 7 - 11. Saiia, D.H., Carroll, A.B. and Buccholz, A.K. (2003). Philanthropy as strategy when corporate charity 'begins at home', Business and Society 42 (2) pp. 169 - 201.

Scherer, K. (1997). Women directors. Talent before gender, Corporate Board Vol. 17 pp. 1 - 5.

Seifert, B. Morris, S.A. and Bartkus, B.R. (2004). Having, giving and getting: Slack resources, corporate philanthropy, and Firm financial performance, Business and Society 43 (2) pp. 135 - 161.

Stephenson, C. (2004). Leveraging diversity to maximum advantage. The business case for appointing more women to board, Ivey Business Journal. Vol. 69 No. 1 pp.1 - 5.

Siciliano, J.I. (1996). The relationship of board member diversity to organizational performance, Journal of Business Ethics. 15:1313 - 1320.

Terjesen, S. Sealy, R. and Singh, V. (2009). Women directors on corporate boards: A review and research agenda, Corporate Governance: An International Review. 17 (3): 320 - 337.

Tsoutsoura, M. (2004). Corporate social Responsibility and Financial performance, Applied financial project. Haas school of business. University of California, Berkely. 
Uwalomwa, U.N. (2011). An empirical investigation of the association between firms' characteristics and corporate social disclosures in the Nigeria financial sector, Journal of Sustainable Development in Africa. Vol. 13. No. 1 pp. 60 -74 .

Waddock, S. and Graves, S. (1997). The Corporate Social Performance-financial performance link, Strategic Management Journal 13 pp 234 - 253.

Williams, R.J. (2003). Women on corporate boards of directors and their influence on corporate philanthropy, Journal of Business Ethics 41 (1) pp 1 - 10.

\section{Appendix 1}

\begin{tabular}{|c|c|c|}
\hline $\mathbf{S} / \mathbf{N}$ & SAMPLE COMPANIES & SECTOR \\
\hline 1. & DN MEYER PLC & CHEMICAL AND PAINTS \\
\hline 2. & GLAXO SMITH KLINE CONSUMER & HEALTH CARE \\
\hline 3. & IKEJA HOTELS & TOURISM \\
\hline 4. & CAP PLC & CHEMICAL AND PAINTS \\
\hline 5. & CAPPA D'ALBERTO & CONSTRUCTION \\
\hline 6. & A.G. LEVENTIS & CONGLOMERATES \\
\hline 7. & NIG. AVIATION HANDLING & AIRLINES \\
\hline 8. & ADSWTICH NIG. LTD & SECOND TIER SECURITIES \\
\hline 9. & NIG. WIRE AND CABLES & ENGINEERING TECHNOLOGY \\
\hline 10. & ASHAKA CEM & BUILDING MATERIALS \\
\hline 11. & UNITED NIG. TEXTILE MILLS & TEXTILES \\
\hline 12. & 7 UP BOTTLING COMPANY PLC & FOOD/BEVERAGES AND TOBACCO \\
\hline 13. & UACN & CONGLOMERATES \\
\hline 14. & TRANS NATION WIDE EXPRESS & COMMERCIAL SERVICES \\
\hline 15. & JAPAUL OIL AND MARITIME & MARITIME \\
\hline 16. & BETA GLASS NIG. LTD & PACKAGING \\
\hline 17. & ACADEMY PRESS & PRINTING AND PUBLISHING \\
\hline 18. & MOBIL OIL NIG. PLC & PETROLEUM (MARKETING) \\
\hline 19. & OKOMU OIL PALM PLC & AGRICULTURE/AGRO ALLIED \\
\hline 20. & GUINNESS NIG. PLC & BREWERIES \\
\hline 21. & C AND I LEASING & MANAGED FUNDS \\
\hline 22. & B.O.C GASES PLC & INDUSTRIAL/DOMESTIC \\
\hline 23. & THOMAS WYATT NIG. PLC & COMPUTER/OFFICE EQUIPMENT \\
\hline 24. & RT BRISCOE & AUTOMOBILE AND TYRE \\
\hline 25. & MAY AND BAKER & HEALTH CARE \\
\hline
\end{tabular}

